\title{
無負荷時非接触型力覚提示装置
}

\author{
吉 川 恒 夫* 名 倉 彰 宏*
}

\section{A Touch and Force Display System for Haptic Interface}

\author{
Tsuneo Yoshikawa* and Akihiro Nagura*
}

\begin{abstract}
The importance of force and tactile display in virtual reality technology has been recognized recently and numerous researches have been done including development of various force and/or tactile display devices. However, many of them are always in touch with fingers or hands of operators and it is impossible for an operator to feel difference between contact and non-contact state with a virtual object directly from sensory channel of touch in his/her finger or hand. This paper presents a new haptic display device we have developed which provides both touch and force feeling to the operator's fingers. This device tracks the operator's finger with no contact when the finger is not in contact with any virtual object. It touches and displays force to the finger only when some virtual object is in touch with the finger. A control algorithm for the system to display dynamic virtual objects is given. Preliminary experimental results are also presented.
\end{abstract}

Key Words: Touch and Force Display, Virtual Reality, Dynamic Virtual Object

\section{1.は じめに}

人工現実感の初期の研究は HMD（頭部搭載型ディスプレイ） に代表されるように，おもに視覚や聴覚情報を提示するもので あったが，仮想空間の物体を手を使って直接操作するような場 合には力覚や触覚などの体性感覚の提示も重要であることが認 識されるようになり，様々な力覚提示装置が開発されてきてい る[1].しかし，それらの多くは装着型の装置であり，装置の一 部分が常に操作者の身体に接触するため, 仮想物体に触れてい る状態と触れていない状態との違いを手や指先の触覚から直接 感じることはできない.このことに対処する一つの方法は, 仮 想物体に触れていないときは手先に何も触れないようにし, 触 れたときには, 装置が手先に接触して力覚を提示できるような 提示システムを作製することである．そのためには操作者の指 先の位置を非接触で計測し, その動きに追従できるような装置 が必要となる。

本論文では, そのような装置の一つとして, 指先位置の測定 のためにオン・オフ式の光学式センサを用いた垂直多関節機構 の装置を提案する。また，二次元内で使用できる装置を試作し， それを用いた実験結果について示す。

なお，無負荷時に非接触とする方式の装置としては文献 [2] [3] などですでに開発されているものがあるが, 提案する装置は光

原稿受付 1998 年 4 月 8 日

*京都大学大学院工学研究科

*Faculty of Enginnering, Kyoto University
学式センサを用いているため手先にまったく何も装着する必要 がなく，また，小型・軽量のセンサを用いた簡単な構造であり， 複数の指先で用いる場合への拡張が比較的容易であると考えて いる.

\section{2. 装 置 の 概 略}

提案する装置の基本構造を Fig. 1 に示す. 装置は力覚提示の ためのアーム部と,アーム先端に取り付けられたリング部から なり，オペレータはリングの中に指先を入れて操作する.

アームの各関節軸には, エンコーダが取り付けられている. また,リング取付部の直後には力センサを取り付け，オペレー タがアームに加える力を計測する。リング部にはセンサが取り 付けられていて, 指先のリング中心に対する相対位置を非接触 で計測することができる。

この装置により非接触追従と力覚提示の 2 モードの機能を実

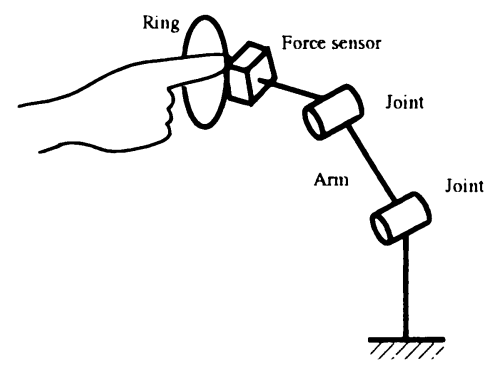

Fig. 1 Basic structure of display device 
現でき，これらのモードが切り換わることにより，操作者は仮 想物体と接触したことを感じることができる.

非接触追従を実現するに当たっての基本的な考え方は以下の とおりである。まず，仮想物体が指先近くに存在しない場合は， 指先をリング中心に保つような制御を行う（Fig. $2(a))$. そし て，指先が仮想物体に接近すると，仮想物体が存在する方向の リング表面を指先と仮想物体の距離に応じて次第に指先に近づ けていき（Fig. 2(b))，指先が仮想物体と接触した瞬間に，指 先とリングとが接触するようにする（Fig. $2(\mathrm{c})$ ).

次に，指先と仮想物体が接触したときには，モードが力覚提

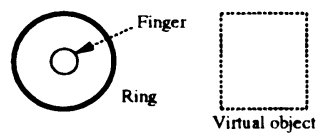

(a) Far away from virtual object

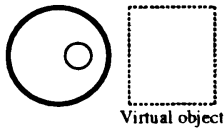

(b) Near virtual object

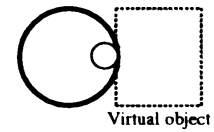

(c) In touch with virtual object
Fig. 2 Relation between fingertip and ring

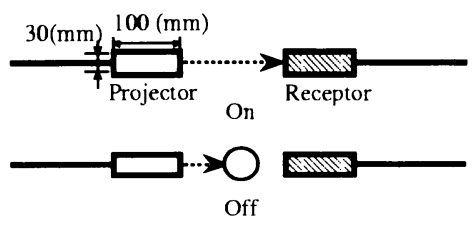

(a) Principle of sensor
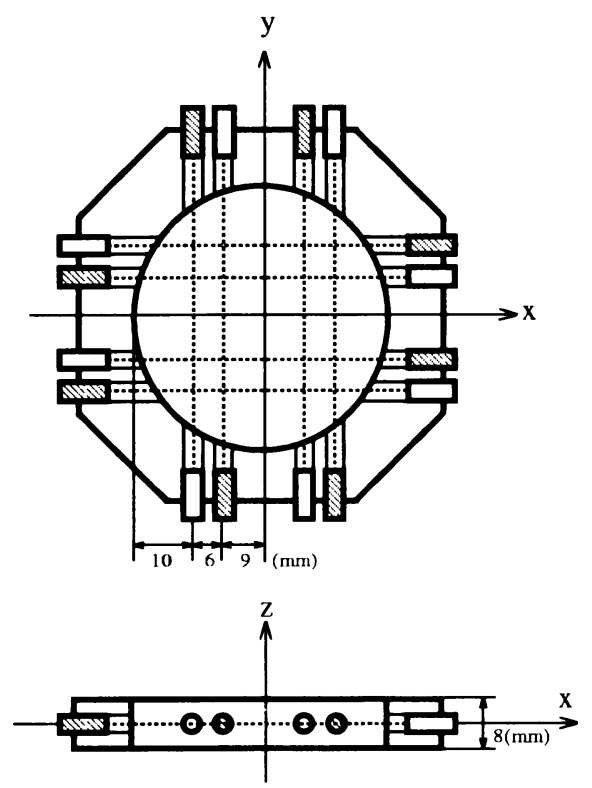

(b) Details of sensor system

Fig. 3 Sensor system of the ring
示モードに移行し相互作用力を以下のように提示する。まず, 指先と仮想物体との位置関係および仮想物体表面の弾性, 摩擦 のモデルにより仮想物体に加えられる力を決定する。この力と 仮想物体の運動方程式を用いて仮想物体の運動を計算する。さ らに仮想物体に加えられる力を指先に実現するようにアームを 制御する。

もちろん，リング部のセンサには，正確な指先位置が計測で きるものを用いるのが理想的であるが，そうしたセンサは一般 に重量が大きく寸法も大きい。そこで，オン・オフ式で小型， 軽量の光学式センサを用い，これをリングに 8 組とりつける

(Fig. 3).このセンサシステムによりリング内でのおおよその 指先位置を測定できる。

\section{3. 非接触追従}

本章では非接触追従モードの制御法について示す。

\section{1 指先位置の推定}

提案した装置では，リング部のセンサがオン・オフ式である ため正確な指先位置の検出はできない。そこで, リング部のセ ンサシステムの情報をもとに指先位置を推定する。

Fig. 3 に示すようにリングに固定した直行座標系を $\sum_{R}$ と する. センサシステムの 4 方向 $\{x+, x-, y+, y-\}$ のうち, 1 方向についてのセン卅と指先との位置関係は Fig. 4 のように 冺の状態に分類できる。この状態に応じて指先の瞬間的な推 定位置 ${ }^{R} \boldsymbol{r}_{f}$ (これを瞬時指先推定位置と呼ぶことにする）の $i$ 方向成分 ${ }^{R} r_{f i}(i=x+, x-, y+, y-)$ を次のように定める.な お， $S_{1}$ はリング中心から内側センサまでの距離， $S_{2}$ は外側セ ンサまでの距離, $R_{r}$ はリング半径, $R_{f}$ は指先半径である.

- 状態 0 のとき

$$
{ }^{R} r_{f i}=0
$$

- 状態 1 のとき

$$
{ }^{R} r_{f i}=\frac{S_{1}+S_{2}}{2}-R_{f}
$$

• 状態 2 のとき

$$
{ }^{R} r_{f i}=R_{r}-R_{f}
$$

ここで瞬時指先推定位置は ${ }^{R} \boldsymbol{r}_{f}=\left({ }^{R} r_{f x+}-{ }^{R} r_{f x-},{ }^{R} r_{f y+}-\right.$ $\left.{ }^{R} r_{f y-}\right)$ で表される。ただ指先がリングの外に出ることはな いので, $\left\|{ }^{R} \boldsymbol{r}_{f}\right\|>R_{r}-R_{f}$ のときは

$$
\frac{R_{r}-R_{f}}{\left\|^{R} \boldsymbol{r}_{f}\right\|} \boldsymbol{r}_{f}
$$

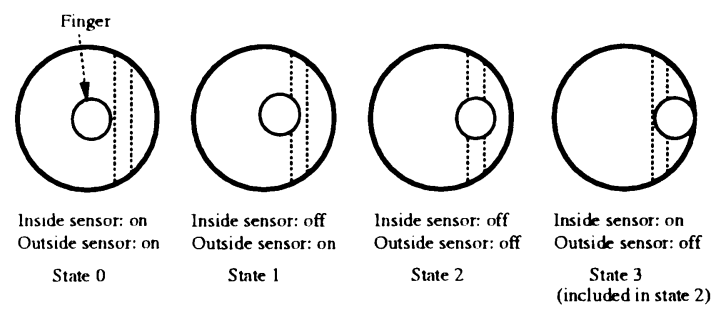

Fig. 4 Three regions of fingertip location 


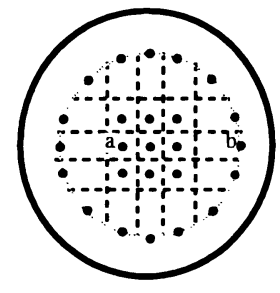

(a) 25 candidates of instantaneous estimate of fingertip position

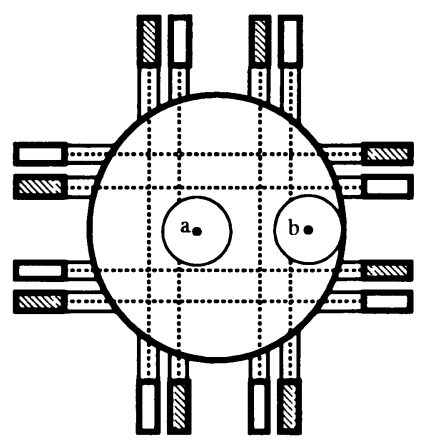

(b) Fingertip location corresponding to $a$ and $b$ in (a)

Fig. 5 Candidates of instantaneous estimate of fingertip position

を新たな ${ }^{R} \boldsymbol{r}_{f}$ とする.

上記の手順で与えられる ${ }^{R} \boldsymbol{r}_{f}$ は Fig. 5 のような 25 個の点 の一つになる.

ここで, 瞬時指先推定位置は時間的に不連続であるため, こ れを平滑になるようにした平滑指先推定位置 ${ }^{R} \boldsymbol{r}_{d}$ を次式のよ うに定める。

$$
{ }^{R} \boldsymbol{r}_{d}(t)=\left(1-e^{\frac{t_{0}-t}{T}}\right)\left({ }^{R} \boldsymbol{r}_{f}\left(t_{0}\right)-{ }^{R} \boldsymbol{r}_{d}\left(t_{0}\right)\right)+{ }^{R} \boldsymbol{r}_{d}\left(t_{0}\right)
$$

$t$ は時間変数, $t_{0}$ はセンサシステムのオン・オフの状態が変化 した瞬間の時間， $T$ は定数である.

$\sum_{U}$ （装置の基底に固定された座標系）から見た平滑指先推 定位置 $\boldsymbol{r}_{d}$ は

$$
\boldsymbol{r}_{d}=\boldsymbol{r}_{R}+{ }^{U} \boldsymbol{R}_{R}{ }^{R} \boldsymbol{r}_{d}
$$

で与えられる.ただしU $\boldsymbol{R}_{R}$ は $\sum_{U}$ と $\sum_{R}$ の間の回転行列, $\boldsymbol{r}_{R}$ はリング中心の位置べクトルである.

\section{2 リング目標位置の決定}

リング中心の目標位置を $\hat{\boldsymbol{r}}_{R}$ とする.

仮想物体が指先近くに存在しないときは, リング中心を平滑 指先位置 $\boldsymbol{r}_{d}$ に追従させる.すなわち， $\hat{\boldsymbol{r}}_{R}=\boldsymbol{r}_{d}$ である.

指先が仮想物体に近づいたときには，仮想物体の存在する方 向のリング表面を指先に近づけていき，指先が仮想物体に接触 した瞬間に，リングと指先を接触させる，そのために，指先に 最も近い仮想物体表面上の点の指先位置に対するべクトルを $\boldsymbol{d}$ としたとき，\|d\|がある一定距離 $\alpha\left(>R_{r}\right)$ よりも小さくなっ た時点で, リング中心を $\|\boldsymbol{d}\|$ の大きさに応じて, 次第に $\boldsymbol{d}$ の 逆方向にずらしていくことにする。つまり

$$
\hat{\boldsymbol{r}}_{R}=\boldsymbol{r}_{d}+\frac{R_{r}-R_{f}}{\alpha-R_{f}}(\|\boldsymbol{d}\|-\alpha) \frac{\boldsymbol{d}}{\|\boldsymbol{d}\|}
$$

\section{3 制御則}

本節では、リング中心 $\boldsymbol{r}_{R}$ を目標位置 $\hat{\boldsymbol{r}}_{R}$ に追従させる制御 則を与える。

まず，外力が何もかかっていないときのアームの運動方程式 は次式で与えられる。

$$
\boldsymbol{\tau}=\boldsymbol{M}(\boldsymbol{q}) \boldsymbol{J}_{R}^{-1}(\boldsymbol{q})\left[\ddot{\boldsymbol{r}}_{R}-\dot{\boldsymbol{J}}_{R}(\boldsymbol{q}) \dot{\boldsymbol{q}}\right]+\hat{\boldsymbol{h}}(\boldsymbol{q}, \dot{\boldsymbol{q}})
$$

ただし $\boldsymbol{\tau}$ はアームの関節駆動力ベクトル， $\boldsymbol{q}$ はアームの関節変 位ベクトル, $\boldsymbol{M}(\boldsymbol{q})$ はアームの慣性行列, $\hat{\boldsymbol{h}}(\boldsymbol{q}, \dot{\boldsymbol{q}})$ はアームの 遠心力, 粘性摩擦, および重力の項であり， $\boldsymbol{J}_{R}(\boldsymbol{q})$ は $\boldsymbol{r}_{R}$ の $\boldsymbol{q}$ に関するヤコビ行列である。

ここで，文献 [4]の 2 段階制御にあてはめ，線形化補償

$$
\begin{aligned}
& \boldsymbol{\tau}=\boldsymbol{M}(\boldsymbol{q}) \boldsymbol{J}_{R}^{-1}(\boldsymbol{q})\left[\boldsymbol{u}_{r}-\dot{\boldsymbol{J}}_{R}(\boldsymbol{q}) \dot{\boldsymbol{q}}\right]+\hat{\boldsymbol{h}}(\boldsymbol{q}, \dot{\boldsymbol{q}}) \\
& \text { と, サーボ補償 } \\
& \boldsymbol{u}_{r}=-K_{r v} \dot{\boldsymbol{r}}_{R}+K_{r p}\left(\boldsymbol{r}_{d}-\hat{\boldsymbol{r}}_{R}\right)
\end{aligned}
$$

よりなる制御則を用いる。なお， $K_{r v}, K_{r p}$ は速度，位置に関 するフィードバックゲインである.

\section{4. 力 覚 提 示}

本章では指先と仮想物体が接触したときの力覚提示モードの 制御法について示す．まず，文献 [5] [6] を参考に，指先と仮想 物体との位置関係から仮想物体に加えられる力を算出し，その 力が加わったときの仮想物体の運動をその運動方程式から決定 する。さらにその力を指先に実現するような制御則について 示す.

\section{1 仮想物体に加えられるカ}

指先と仮想物体が接触しているとき，その接触状態には静止: 摩擦状態と動摩擦状態の二つがあり，指先から仮想物体には， その状態に応じて次のような力 $\boldsymbol{f}_{c}$ が加えられる。 それは, 静 止摩擦状態のときは, 垂直抗力 $\boldsymbol{f}_{c v}$ と, それと垂直な方向の力 $\boldsymbol{f}_{c t}$ であり, 動摩擦状態のときには, 垂直抗力 $\boldsymbol{f}_{c v}$ と動摩擦力 $\boldsymbol{f}_{c d}$ である.

$\boldsymbol{f}_{c v}$ および $\boldsymbol{f}_{c t}$ は, 目標指先位置からの指先位置のずれの量 （これを $\boldsymbol{e}$ とする）に比例する弾性力が主である。ここで，目 標指先位置は静止摩擦状態のときは, 静止摩擦状態に移行した 瞬間の指先位置とし，動摩擦状態のときは指先に最も近い仮想 物体表面上の点から動摩擦の分だけ速度方向に戻した点とする。 また振動をおさえるために，目標指先位置の速度と指先速度と の差（これを $\dot{\boldsymbol{e}}$ とする）に比例する力をこれに加えることにす る.そうすると,これらの力は

$$
\begin{aligned}
\boldsymbol{f}_{c v} & = \begin{cases}K_{p v} \boldsymbol{e}_{v}+K_{d v} \dot{\boldsymbol{e}}_{v} & : \text { if } \boldsymbol{e}_{v}^{T} \dot{\boldsymbol{e}}_{v}>0 \\
K_{p v} \boldsymbol{e}_{v} & : \text { otherwise }\end{cases} \\
\boldsymbol{f}_{c t} & =K_{p t} \boldsymbol{e}_{t}+K_{d t} \dot{\boldsymbol{e}}_{t}
\end{aligned}
$$

で与えられる．式中の $K$ は仮想物体の弾性および粘性係数で ある。また，添字の $v, t$ はそれぞれ接触点における法線方向， 接線方向を表す。

動摩擦力 $\boldsymbol{f}_{c d}$ は指先が滑る方向に垂直抗力に比例する大き さで働く力であり，その方向の単位ベクトルを $n$ とすると

$$
\boldsymbol{f}_{c d}=\mu_{d}\left\|\boldsymbol{f}_{c v}\right\| \boldsymbol{n}
$$

と表される， $\mu_{d}$ は仮想物体の動摩擦俰数である.

ここで, 静止摩擦状態か動摩擦状態かの判断は, 次のように 行う. 
・接触した瞬間は, 滑り速度が 0 , すなわち $\|\dot{e}\|=0$ であ れば静止摩擦状態，それ以外のときは動摩擦状態とする。

・直前が動摩擦状態のときは, 滑り速度が 0 ならば静止摩擦 状態になる。

・直前が静止摩擦状態のときは, $\left\|\boldsymbol{f}_{c t}\right\|>\mu_{s}\left\|\boldsymbol{f}_{c v}\right\|$ ならば 動摩擦状態になる。ただし $\mu_{s}$ は仮想物体の最大静止摩擦 係数である。

\section{2 仮想物体の運動方程式}

前節では弾性モデルをもとに相互作用力を計算しているが， ここでは弾性は小さく仮想物体は剛体であると仮定し，その運 動方程式を次のように与える。

$$
\begin{aligned}
M \ddot{\boldsymbol{r}}_{G} & =M \boldsymbol{g}+\boldsymbol{f}_{c} \\
I \dot{\omega} & =\left\|\boldsymbol{r}_{G i}\right\|\left\|\boldsymbol{f}_{c}\right\| \sin \theta
\end{aligned}
$$

ただし $\boldsymbol{f}_{c}$ は指先力, $\boldsymbol{r}_{G}$ は質量中心の位置ベクトル， $\boldsymbol{r}_{G i}$ は 接触点の質量中心 $\boldsymbol{r}_{G}$ に対する相対位置ベクトル， $\omega$ は角速度， $M$ は質量, $I$ は質量中心まわりの慣性モーメント, $\boldsymbol{g}$ は重力加 速度ベクトル, $\theta$ は $\boldsymbol{r}_{G i}$ と $\boldsymbol{f}_{c}$ のなす角度である。

\section{3 制御則}

本節では, 4.1 節で求めた仮想物体に加えられる力 $\boldsymbol{f}_{c}$ を指 先に㥶現するための制御則を示す。

ここでも非接触追従の場合と同様，2段階制御を用いる。ま ず、リングに外力 $\boldsymbol{F}$ が加えられたときのアームの運動方程式は

$$
\boldsymbol{\tau}=\boldsymbol{M}(\boldsymbol{q}) \ddot{\boldsymbol{q}}+\hat{\boldsymbol{h}}(\boldsymbol{q}, \dot{\boldsymbol{q}})-\boldsymbol{J}_{R}^{T}(\boldsymbol{q}) \boldsymbol{F}
$$

で与えられる。線形化補償は

$$
\boldsymbol{\tau}=\boldsymbol{M}(\boldsymbol{q}) \ddot{\boldsymbol{q}}+\hat{\boldsymbol{h}}(\boldsymbol{q}, \dot{\boldsymbol{q}})-\boldsymbol{J}_{R}^{T}(\boldsymbol{q}) \boldsymbol{u}_{f}
$$

PI 動作のサーボ補償を行って

$$
\boldsymbol{u}_{f}=\boldsymbol{f}_{c}+K_{f P}\left(\boldsymbol{f}_{c}-\boldsymbol{f}_{R}\right)+K_{f I} \int\left(\boldsymbol{f}_{c}-\boldsymbol{f}_{R}\right) d t
$$

ここで, $K_{f P}, K_{f I}$ は力に関するフィードバックゲイン,$f_{R}$ は力センサより得られる指先力である。ただし， $\boldsymbol{f}_{c}$ はリング 接線方向の力も含むので, 指先とリングの間の摩擦倸数はこれ を提示できるよう十分大きくするものとする。

\section{5. 実験}

\section{1 システム構成}

システムの構成をFig. 6 に示す。装置の外観を Fig. 7 に， 操作しているときの様子を Fig. 8 にそれぞれ写真で示す.

アームには垂直多関節型ロボットであるダイキン工業（株） 製研究用ミニチュアロボットを一軸を固定し 2 自由度マニピュ レータとして用いた. カセンサは $4.9[\mathrm{~N}](=500$ [gf $])$ まで測定 可能である. 関節角の測定には, 出力パルス数 $500 \mathrm{P} / \mathrm{R}$ のオプ ティカルエンコーダを減速比 $1: 8$ で用い, 関節駆動には定格卜 ルク $35[\mathrm{~N} \cdot \mathrm{mm}](=3,600$ [gf.mm]) の DC サーボモータを減速 比 $1: 8$ で用いた。リング部のセンサには KEYENCE 製ファイ バセンサ（ $\phi 3[\mathrm{~mm}]$, 約 $1[\mathrm{~g}]$, 応答時間 $0.5[\mathrm{msec}] ）$ を用いた。

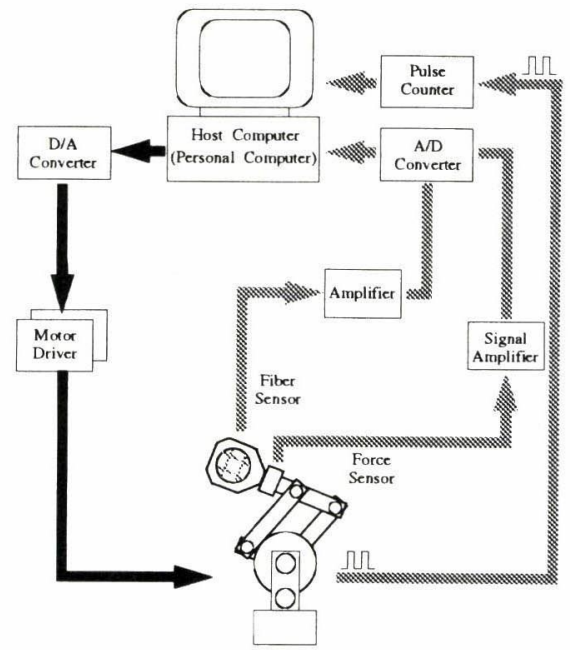

Fig. 6 Outline of experimental system

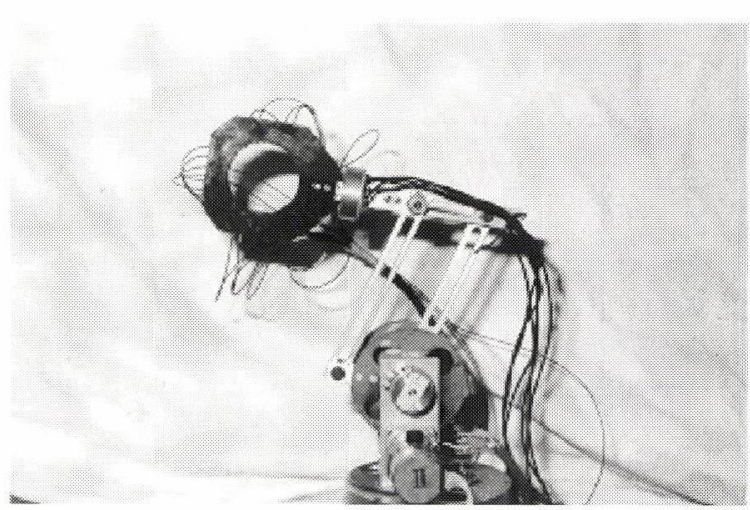

Fig. 7 Touch/force display device

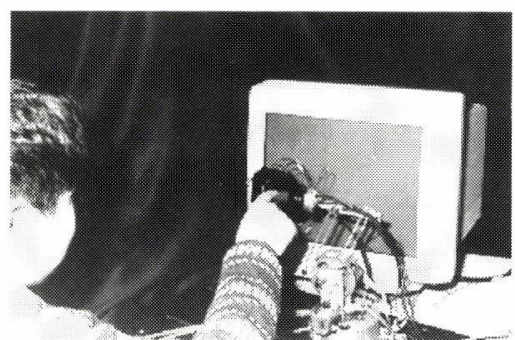

Fig. 8 An operator manipulating the display device

\section{2 実験方法}

以下のような実験を行った。

（1）仮想物体から離机た位置で指先を動かし，そのときの指先 とリング中心の位置を比較することにより指先への非接触 追従の能力在確垫する。

（2）仮想壁に触れる実験を行い，指先が仮想壁と接触したとき にリングが指先と接触し，力覚を提示できていることを確 認する。

（3）円板を操作し動特性，摩擦が提示できているかを確認する. これらの寨験に用いたパラメータ等を以下に示寸。 


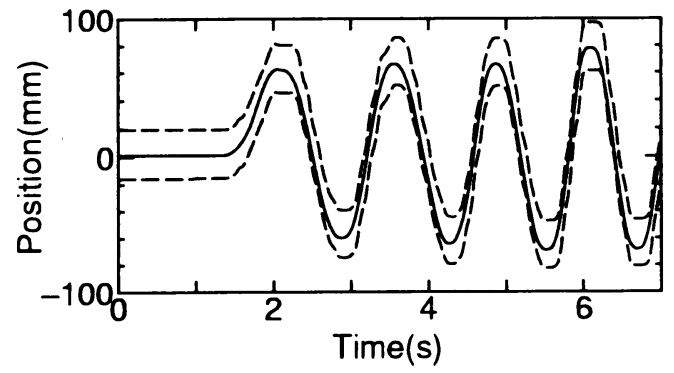

(a) Fingertip position

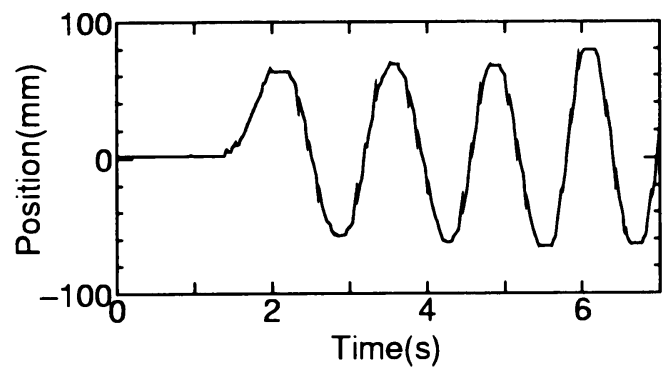

(b) Smoothed estimate of fingertip position

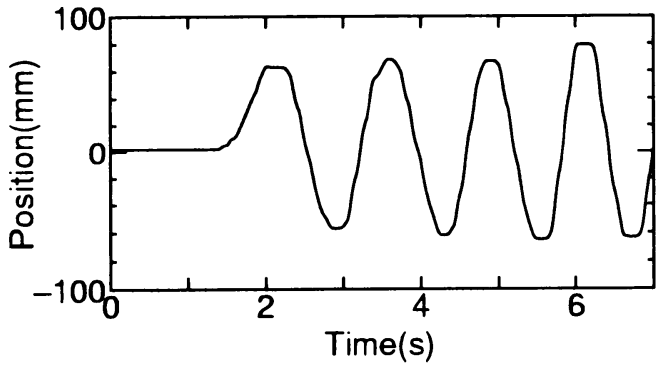

(c) Position of ring center

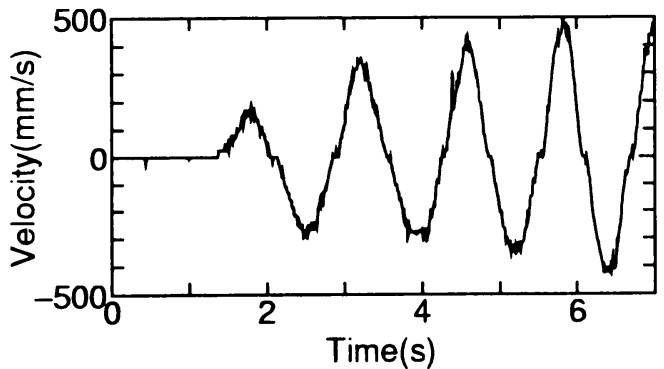

(d) Velocity of fingertip

Fig. 9 Experimental result 1

リング半径は $R_{r}=25[\mathrm{~mm}]$ であり, 式 (7) の $\alpha=35[\mathrm{~mm}]$ とした。式（5）の $T$ については $0.02[\mathrm{~s}]$ 前後で定めた.

位置, 速度に関するフィードバックゲインは， $K_{r p}=$ $2,000\left[1 / \mathrm{s}^{2}\right], K_{r v}=40[1 / \mathrm{s}]$, 力䛊差のフィードバックゲイ ンは, $K_{f P}=0.3, K_{f I}=1.0[1 / \mathrm{s}]$ とした.

仮想壁の弾性係数は $K_{p v}=80[\mathrm{gf} / \mathrm{mm}]$, 粘性係数は $K_{d v}=0.1[\mathrm{gf} \cdot \mathrm{s} / \mathrm{mm}]$ とした.

また，仮想门板の弾性係数は $K_{p v}=80[\mathrm{gf} / \mathrm{mm}]$, 粘性係数 は $K_{d v}=0.2[\mathrm{gf} \cdot \mathrm{s} / \mathrm{mm}]$, 質量は $3,000[\mathrm{~g}]$ で密度は一定とし

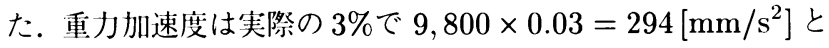
した.

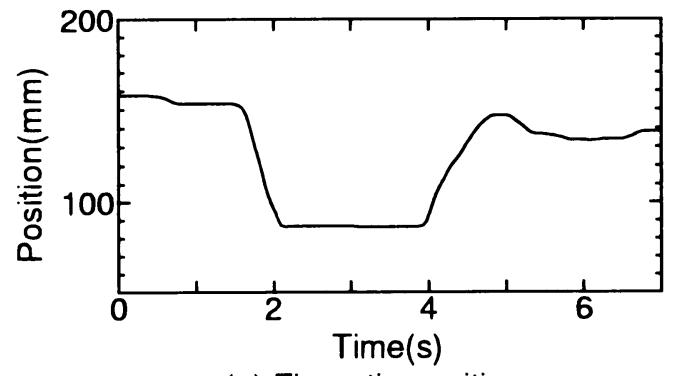

(a) Fingertip position

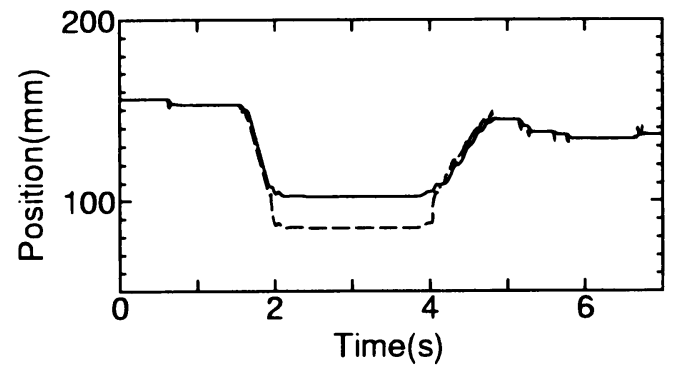

(b) Position of ring center

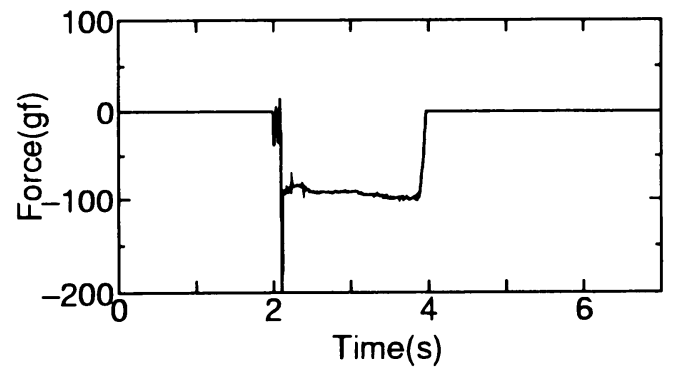

(c) Calculated fingertip force against wall

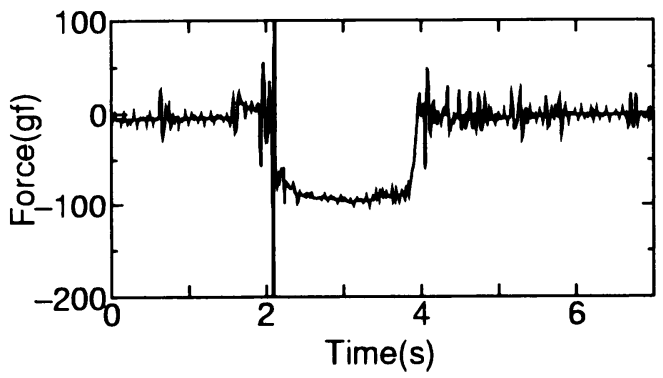

(d) Realized fingertip force

Fig. 10 Experimental result 2

サンプリングタイムは実験 1,2 では約 $2[\mathrm{~ms}]$, 実験 3 では 約 $3.5[\mathrm{~ms}]$ であった。

基準座標系は提示装置に向かって右へ $x$ 軸，上へ $y$ 軸を とった。

なお，試作装置と同様の機構のアーム先端を指先にとりつけ， 実際の指先位置を測定した。

\section{3 実験結果}

実駼 1 では，指先を高さ一定で左右に動かした，Fig.9 は このときの $x$ 方向についての (a) 指先位置 (実線), (b) 指先 の推分位置, (c) リング中心の位置, (d) 指先の速度を表して いる. (a)の点線はリングの穴の位置から指先半径の分だけ縮 


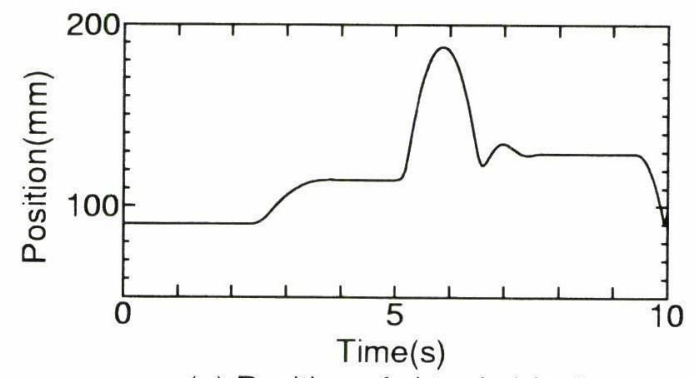

(a) Position of virtual object

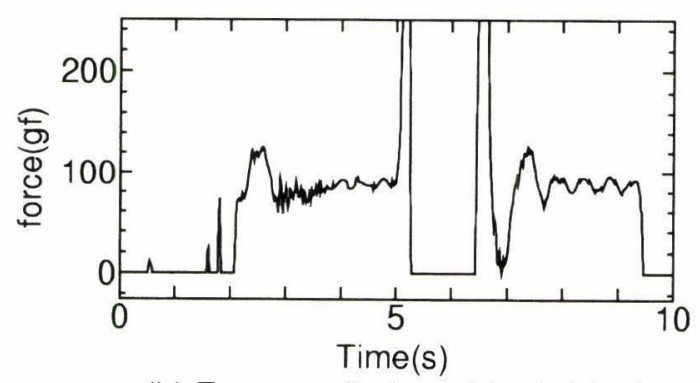

(b) Force applied on virtual object

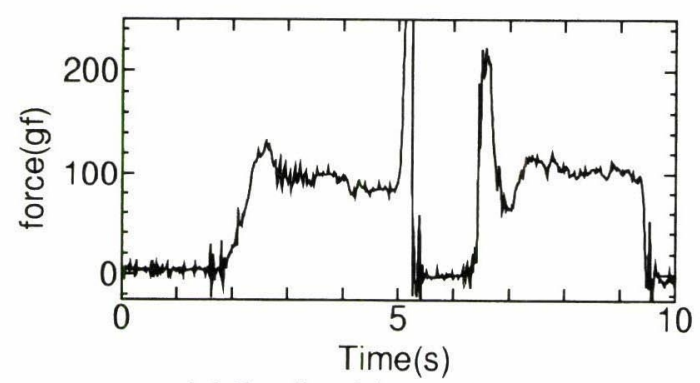

(c) Realized force at fingertip

Fig. 11 Experimental result 3

めた位置である。この点線の範囲内に指先中心があるので，指 先がリングと触れていないことが分かる。また，指先速度が $500[\mathrm{~mm} / \mathrm{s}]$ 程度でも，リングを指先に非接触で追従させるこ とができている。

実験 2 では, 基準座標の $y=80[\mathrm{~mm}]$ の位置に水平な仮想 壁を設定し，指先をその仮想壁と接触させるように動かした，

Fig. 10 はこのときの $y$ 方向についての (a) 指先位置, (b) リン グ中心の位置，(c) 指先から仮想壁に加えられる力, (d) 指先に 実現された力である。はじめ指先中心とリング中心の位置はほぼ
致しているが，指先が仮想壁に近づくに従いリング中心が次 第に指先中心からはずれてくる，そして指先が仮想壁と接触し た時点で, 指先とリングが接触し, 操作者は接触感をはっきり 感じることができる，またこのとき，指先には仮想壁に加えら れる力とほぼ等しい大きさの力が提示されている.

実験 3 では，仮想円板を投げ上げて落ちてくるのを受けとめ る動作をした. Fig.11 はこのときの $y$ 方向についての (a) 仮 想物体の位置, (b) 仮想物体に加えられる力, (c) 指先に実現さ れた力である。持ち上げているときには，ほほ仮想物体の重量 に等しい $90[\mathrm{gf}]$ 前後の力がかかっていること，また，投げ上げ た瞬間と受けとめた瞬間に衝撃力がかかっていることが読み取 れる.

\section{6. おわりに}

本論文では，通常は非接触で指先に追従し，仮想物体と指先 が接触したときにのみ, 指先と装置の一部を接触させ力覚の提 示ができるような装置を小型, 軽量の光学式センサを用いて試 作した。また，仮想物体の運動を考慮した装置の制御法につい て示した。さらに実験により, 接触, 非接触の感覚の表現, ま た，仮想物体を操作するときにオペレータが受ける力の提示に， 装置が有効であることを確認した。

\section{参 考 文 献}

[1] T. Yoshikawa and H. Ueda: "Haptic Virtual Reality: Display of Operating Feel of Dynamic Virtual Objects," Proc. of the 7th International Symposium of Robotics Research, pp.191$198,1995$.

[2] K. Hirota, J. Saito and M. Hirose: "Force Display depending on Mock Surface Method," Proceedings of the Annual Conference of the Robotics Society of Japan, pp.355-356, 1993.

[3] M. Inami, N. Kawakami, S. Hasegawa and T. Hatakeda: "Design and Application of a Non-Contact Tracking Force Display "ARMS-III" ," Proc. of the 11th Symposium on Human Interface, pp.505-510, 1995.

[4] T. Yoshikawa: Foundations of Robotics. MIT Press, Cambridge, Mass., 1990.

[5] T. Yoshikawa, Y. Yokokohji, T. Matsumoto and Xin-Zhi Zheng: "Display of Feel for the Manipulation of Dynamic Virtual Objects," ASME J. Dynamic Systems, Measurement and Control, vol.117, no.4, pp.554-558, 1995.

[6] T. Yoshikawa and H. Ueda: "Construction of Virtual World Using Dynamics Modules and Interaction Modules," Proceedings of IEEE International Conference on Robotics and Automation, pp.2358-2364, 1996.

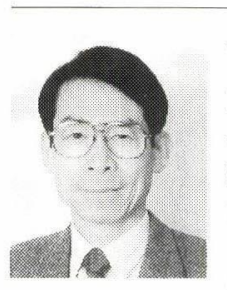

吉川恒夫 (Tsuneo Yoshikawa)

1941 年 12 月 19 日生. 1969 年京都大学大学院博 士課程修了. 同年, 同大学工学部助手. 同助教授老 経て 1986 年同教授. 1994 年組織変更により，同 大学大学院工学研究科教授 (機械工学専攻) とな り現在に至る、ロボット工学掞よび制御工学:の研究 に従事. システム制御情報学会, 計測自動制御学 会, 日本機械学会, 日本バーチャルリアリテイ学会, IEEE などの会 員.

(日本ロボット学会正会員)

\section{名倉彰宏 (Akihiro Nagura)}

1973 年 12 月 31 日生. 1996 年京都大学工学部機 械工学科卒業. 現在京都大学大学院工学研究科修 士課程在学中. 人丁.現実感の研究に従事.

(日本ロボット学会学生会員) 